\title{
Covid-19: UK's chief scientific officer defends make up of advisory group
}

\author{
Jane Feinmann
}

London, UK

Public health specialists have reacted with incredulity to an assurance from the UK's chief scientific officer Patrick Vallance that public health is adequately represented on the Scientific Advisory Group for Emergencies (Sage) because "at least four people from Public Health England (PHE) are at every meeting" with other public health specialists called in when they are needed.

Vallance made the claim at a briefing for science and medical journalists on 27 April following the publication on Friday by the Guardian of the names of 23 attendees at Sage comprising 21 scientists and two Downing Street political advisers.

Vallance's assurances have failed to allay concern that secrecy over the membership of Sage is hiding the fact that the public health sector is barely or not represented in the group.

Gabriel Scally, professor of public health and planning at the University of the West of England, said that Vallance's claim that public health expertise was represented by PHE employees demonstrated "extraordinary ignorance about public health."

"He appears to believe that 'working for PHE' guaranteed training, qualifications, and experience in public health and the management of disease outbreaks," Scally told The BMJ.

"Sage is in a mindset that I call 'scientistic'-producing theses then testing them and producing antitheses. We are heading down a unique path instead of getting on with the job of managing an unprecedented public health emergency."

Allyson Pollock, a public health doctor and director of the Newcastle University Centre of Excellence in Regulatory Science said of PHE members of Sage: "These are mostly microbiologists. They are vital but it's not the same as having expertise in communicable disease control.

"Microbiologists look at bugs and viruses in respect of patients whereas public health doctors, public health teams, and consultants in communicable disease control are trained in disease surveillance and seek to understand the modes of transmission and risks to their population in order to prevent spread in the community locally and nationally."

Concern about Sage's secrecy has been growing in recent weeks. On 21 April, Anne Glover, special advisor to the principal at the University of Strathclyde and president of the Royal Society of Edinburgh, told Channel 4 News that she was "very concerned" that the membership and minutes of Sage meetings were not being made public.
"I understand no reason why that should be kept secret. It's really important to be open and transparent for no other reason than that's the way you ensure trust in what you are doing," she said.

Worries about Sage's lack of transparency peaked last Friday with the revelation by the Guardian that Dominic Cummings, Boris Johnson's most senior aide, was a member of the committee. Cummings had been an active participant at several of the 28 covid-19 meetings that Sage has held since its first meeting on 29 January. It's Sage's ninth emergency since it was set up 11 years ago.

Vallance said that the identities of Sage experts are usually revealed after an emergency is over. But he said: "I now believe we should be more prepared to publish names sooner and intend to do so shortly. We will be publishing the names of those that are happy to have their names published-along with a list of documents and eventually the documents themselves that have fed into Sage meetings."

Reports have also suggested that Sage members fear they may be used by government ministers as "human shields" at a future public inquiry.

An article on the online news blog buzzfeed.com reported that some Sage advisers are worried that they "will be held responsible by Boris Johnson's political team for the UK taking longer than other European countries to enforce social distancing in March, if this decision is found to have led to excess deaths in Britain'."

It said the concern was fuelled by a chorus of claims by ministers, including Dominic Raab at Prime Ministers Questions on 22 April, that they were "guided by the science"-even though in reality the science of this crisis had been "riddled with doubt, uncertainty, and debate," Buzzfeed quoted Robert Dingwall, a member of the New and Emerging Respiratory Virus Threats Advisory Group, which advises Sage, as saying.

Vallance said on 27 April, "Scientists on Sage do not make decisions. It is the government that makes decisions. The science, the evidence, is just one element of policy making along with making those policies deliverable." He said the evidence of the health benefits of lockdown had to be seen alongside "the challenges of overall wellbeing and the economy. It's not simply about pressing the science button."

Vallance said he could not rule out that Cummings would share his opinion with the prime minister. "All I know is that I make my output from Sage the official output from Sage and we both 
have regular meetings with all of the appropriate senior politicians."

\section{Members of Sage as named by the Guardian}

Patrick Vallance, chief scientific and former president of research and development at GlaxoSmithKline

Chris Whitty, England's chief medical officer, epidemiologist who has devoted much of his career to malaria research in Africa

Jonathan Van-Tam, deputy chief medical officer. Professor of health protection at the University of Nottingham's school of medicine

Stephen Powis, national medical director, NHS England and a professor of renal medicine at University College London

Sharon Peacock, director of the National Infection Service at PHE, professor of public health and microbiology at the University of Cambridge. She is known for her work on the use of microbial whole genome sequencing in diagnostic and public health microbiology

Maria Zambon, director of Reference Microbiology Services at PHE, a virologist and head of the UK WHO National Influenza Centre. She is a specialist on RNA viruses, antivirals, and vaccines

Meera Chand, consultant microbiologist at PHE and a consultant with the Department of Infectious Diseases, Guy's and St Thomas' NHS Foundation Trust

Charlotte Watts, chief scientific adviser to the Department for International Developmen

lan Diamond, head of the Government Statistical Service and chief executive of the UK Statistics Authority

Graham Medley, professor of infectious disease modelling at the London School of Hygiene and Tropical Medicine

Neil Ferguson, professor at Imperial College London faculty of medicine John Edmunds, specialist in design of control programmes against infectious diseases at the London School of Hygiene and Tropical Medicine James Rubin, reader in psychology of emerging health risks, Kings College London

Brooke Rogers, professor of behavioural science and security at Kings College London

Peter Horby, former professor of infectious diseases and global health at University of Oxford and chair of government's New and Emerging

Respiratory Virus Threats Advisory Group Jeremy Farrar, director of the Wellcome Trust

Andrew Rambaut, member of the Institute of Evolutionary Biology at Edinburgh University's school of biological sciences

Emma Reed, director of emergency response and health protection at the Department of Health and Social Care

Edward Mullins, clinical advisor to the chief medical officer Dominic Cummings, chief adviser to the prime minister

Ben Warner, Downing Street adviser on data science wh,o with his brother Marc, worked with Dominic Cummings on the Vote Leave campaign. Marc Warner "won a £250m NHS contract when Cummings entered Downing Street and his company, Faculty, has the contract for the NHS tracking app," according to journalist Carole Cadwalladr, writing on Twitter, 26 April. 